\title{
Teaching the Effect of Liming Concentration on Mechanical Characteristics of Cowhide Crackers for Senior High School Students
}

\author{
Sri Anggraeni, Rahma Maulida, Risti Ragadhita, Siti Nur Hofifah, Asep Bayu Dani Nandiyanto \\ Universitas Pendidikan Indonesia, Jl. Dr. Setiabudi No. 229 Bandung, Indonesia \\ anggraeni_said@upi.edu,rahma.m15@upi.edu, ristiragadhita@upi.edu, sitinurhofifah@upi.edu, nandiyanto@upi.edu
}

\begin{abstract}
The purpose of this study is to analyze the effect of liming concentration on the mechanical characteristics of cowhide crackers and to analyze the results of learning science about food mechanical characteristics related to the food chemical composition in high school students. The cowhide crackers production is carried out through the process of washing, liming, deliming, cutting, seasoning, drying, and frying the cowhide. The mechanical characteristics of the cowhide crackers were tested through the hardness and puncture strength test. Also, teaching and learning are conducted using experimental demonstration methods to 18 students through three stages, namely given a pretest; given an instructional video, and given posttest. The results of the research from cowhide crackers production with various concentrations show that the best cowhide crackers are obtained at a liming concentration of 93 grams because of the better level of crispiness than others. The mechanical properties change due to lime reduce the water and protein content in cowhide. The learning result about effect of food chemical composition on mechanical composition on cowhide crackers showed that experimental demonstration is effective in improving student learning outcomes because the average posttest score after video presentation is higher than pretest score. Furthermore, this research is important to analyze and inform the effectiveness of the use of instructional media in the science teaching and learning process.
\end{abstract}

Keywords: Food Chemical Composition, Experimental Demonstration, High School Student, Science Education.

\section{Corresponding Author}

*Departemen Pendidikan Kimia, Universitas

Pendidikan Indonesia, Jl. Dr. Setiabudi No. 229

Bandung, Indonesia

*nandiyanto@upi.edu

\section{Introduction}

Cowhide crackers are one type of Indonesian traditional food that is favored by many people. Cowhide crackers are usually made from animal skin which is processed with the addition of spices and flavor enhancers (Nakov and Ivanova, 2020). Many people like cowhide crackers because it has dry and crunchy attributes. Many factors affect the quality of the cowhide crackers produced, such as the raw materials used and the method of production (Ahmed, Satheesh, and Dibaba, 2018). In the cowhide crackers industry, people use lime for the liming process. The liming process is one of the processes that affect the mechanical characteristics of cowhide crackers (Purba, Suparno, and Suryani, 2020).

The mechanical characteristics of these foods are related to the chemical composition present in food (Lucky, Hosen, Toma, and Mazumder, 2020; Nishio, Ito, Takata, Goshima, Matsushita, Nakamura, and Yamauchi, 2020). Therefore, learning material about the mechanical characteristics of food is an interesting science subject to be taught to high school students to convey the subject of food chemical composition. To facilitate the transfer of knowledge from teachers to students, science learning materials about food chemical composition are taught to students through demonstration method, thus, the abstract content and the daily reality can be interpreted by students. The learning method that is carried out through demonstration is referred to as the experimental demonstration learning method (Daluba, 2013; Husni, 2020; Nandiyanto, Raziqi, Dallyono and Sumardi, 2020).

Recently, many studies about experimental demonstration methods have been carried out, as conducted by Hidayat, Rahmat, Fattah, Rochyadi, Nandiyanto, and Maryanti (2020) which explains that experimental demonstrations increase student focus and succeed in helping students understand the subject matter. Widodo, Hufad, Sunardi, and Nandiyanto (2020) explain that the experimental demonstration learning method makes students with slow learning more focused on the ability to capture the material being taught. Besides, another study also explained that the experimental demonstration method is a model that attract students' interest to learn more actively during the learning process (Handayani, Hufad, Tukimin, Rochyadi, and Nandiyanto, 2020). This experimental demonstration learning method shows a lot of success to help students understand the subject matter and increase student interest in 
learning. However, research on experimental methods to teach science matter for high school students not much done.

Therefore, the novelty of this study is to teach high school student about mechanical characteristics of food that correlated with food chemical composition scientifically through an experimental demonstration using video-based learning. The purpose of this study is to determine the results of high school students' science learning regarding food mechanical characteristics and chemical compositions, specifically in cowhide crackers. The learning method used in this study is an experimental demonstration method through the presentation of the pretest, instructional videos, and posttest. Researchers chose instructional video media because the instructional video media can display information or events without having to experience it firsthand. It is expected that the approach would be useful for demonstrating certain skills, promoting explanation and teaching skills so that it will have a positive impact on students and will be able to enhance student learning outcomes.

\section{Method}

\subsection{Material}

The main ingredients used in this study are fresh cowhide, lime, salt, garlic, oil (Bimoli), and distilled water. Cowhide is obtained Pasar Induk Terminal, Subang, Indonesia.

\subsection{Teaching Method}

Figure 1 shows an illustration of the process of cowhide crackers production. Cowhide is collected, washed with water to clean the remaining meat, feather, bones, and dirt that are still attached on cowhide. The clean cowhide is then soaked in water without liming and soaked in various concentrations of liming (31, 62, and 93 grams) for an hour. Then, cowhide is washed again to remove the remaining lime (deliming process). Next, cowhide is boiled at \pm 100 $150^{\circ} \mathrm{C}$ for 15 minutes until the cowhide is cooked. After that, the cowhide is cut into small pieces to a thickness of 1.1 $1.4 \mathrm{~mm}$ and soaked in spices. The spices used are garlic and salt which are crushed and dissolved in water. After that, the cowhide is dried until it is completely dry and finally fried. The frying process is carried out in two stages, the first frying uses warm oil with a temperature of $\pm 80^{\circ} \mathrm{C}$, while the second frying uses hot oil with a temperature of $\pm 100-150^{\circ} \mathrm{C}$.

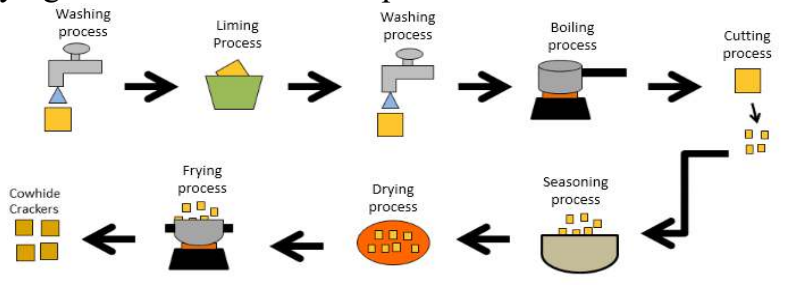

Fig 1. Illustration process of cowhide crackers production

\subsection{Physical and Mechanical Characteristic Test of Cowhide Crackers}

Physical characteristics of crackers analyze using a microscope. To determine the mechanical characteristics of the cowhide crackers, the hardness, and crispness test is carried out using a hardness test using the Screw Stand Test Instrument (Mode I ALX-J, China) equipped with a measuring instrument (a Digital Force Gauge (Model HP500, Serial). No. H5001909262)) and puncture strength test using the Shore Durometer instrument (Shore A Hardness, In size, China). In the hardness test, the measurement is conducted by applying a compressive force to the cowhide crackers to produce a curve showing the texture profile of the cowhide crackers. Hardness is expressed as the maximum force (peak value) in Newton $(\mathrm{N})$ units. The puncture strength test is carried out by measuring the force by inserting a needle or probe into several points on the surface of the cowhide crackers until the surface becomes hollow and the texture profile is obtained.

\subsection{Biodegradation Test of Cowhide Crackers}

To determine the degradation process of cowhide crackers, a biodegradation test is performed. In the biodegradation test, the samples with a length and width of $1-2 \mathrm{~cm}$ and a height of $0.5-1 \mathrm{~cm}$ are weighed and then immersed in a small bottle containing $60 \mathrm{~mL}$ of distilled water and tightly closed for 1, 2, 4, 6, 8, 10, and 14 days.

Then, the sample is placed in a place that is not exposed to direct sunlight. After reaching the specified time, the sample is removed and dried in an oven with a temperature of $100^{\circ} \mathrm{C}$ for $30-45$ minutes. Samples are weighed again to determine the percentage of weight loss. The data obtained from the biodegradation test is a percentage of weight loss.

\subsection{Teaching Method}

The learning method used in this study is an experimental demonstration method. The subjects in this study are 18 high school students in Subang, Indonesia. These 18 high school students are majoring in science, consisting of 12 female and 6 male students.

The transfer of science material is carried out in several stages including providing a pretest to measure the condition of student motivation before given treatment using video learning. The next stage is presenting the learning video which contains a brief explanation of science material. Then, the final stage is giving posttest questions to measure the condition of learning motivation after given the learning video treatment. The pretest and posttest questions contain 17 short answers with true or false answers. The analysis score for answering the statement correctly is 1 while the incorrect answer is given a value of 0 . If the student answers all the questions correctly, the maximum score is 100 .

Furthermore, the learning outcomes are analyzed using paired $\mathrm{t}$-Test statistical calculations to determine the significance level of the experimental demonstration learning method. To support the research instrument, students' basic information on the average scores of Mathematics, Chemistry, Physics, and Biology are obtained before learning. 


\section{Results and Discussion}

\subsection{Physical and Mechanical Characteristics of Cowhide Cracker}

Compositions in the material influenced the mechanical properties of the material (Nandiyanto, Fiandini, Ragadhita, Sukmafitri, Salam, and Triawan, 2020). This makes the need for analysis of the mechanical properties of cowhide crackers.

Figure 2 (a-d) are the physical appearance of the cowhide crackers prepared with various liming concentration and without liming process where all cowhide crackers have the same physical appearance and have an uneven surface.

Figure 2 also displays color differences. This color difference is caused by Maillard's reaction when frying. Maillard reaction is a reaction between carbohydrates, in particular sugar-reducing, and primary amine groups resulting in a brown product. This Maillard reaction is influenced by the water content in the crackers and cooking method (Tavares, Dong, Jin, Yang, Han, Zha, and Zeng, 2018). High water content decreases the Maillard reaction rate and low water content increase the Maillard reaction rate. The moisture content is associated with the liming process. The higher the concentration of the liming phase, the lower the water content of the crackers which becomes brown. Therefore, cowhide crackers without liming (which have a higher moisture content than other cracker samples) do not have a darker color than crackers that have been liming process. However, in Figures 2 (b and $f$ ) and also (d and $\mathrm{h}$ ) crackers with a liming process at high concentration variations (32 and 93 grams respectively) produce a darker color, this is due to the too long frying process, thus, affect on Maillard formation process (Starowicz and Zieliński, 2019; Tavares, Dong, Jin, Yang, Han, Zha, and Zeng, 2018). Water activity, in this case, is not the major factor for browning.

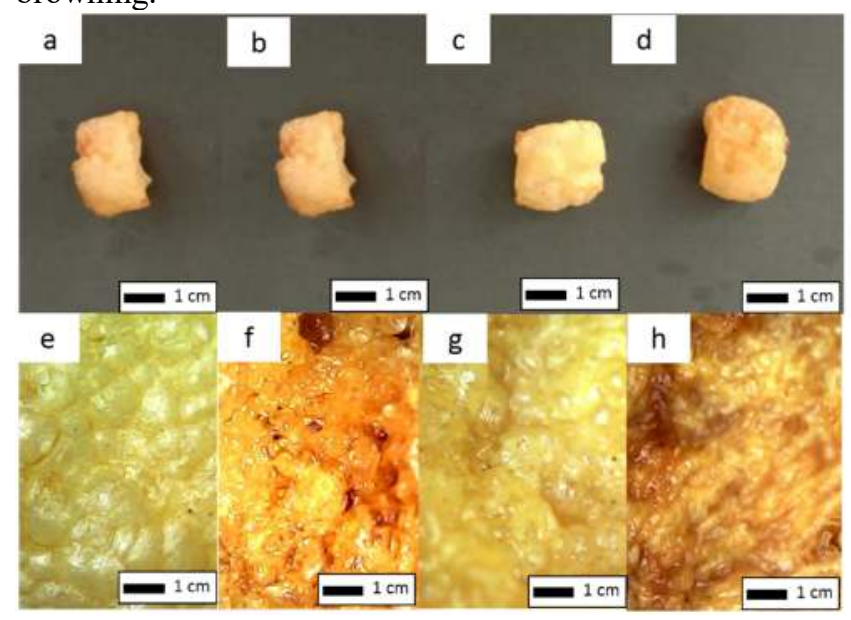

Figs. 2 Physical Appearances of Cowhide Crackers samples with various liming concentration: without liming process (a and e), liming process in 31 grams of lime (b and f), a liming process in 62 gram of

lime (c and g), and liming process in 93 grams of lime (d and $h$ )

Figure 3 shows the hardness test results of the cowhide crackers. Based on Figure 3, cowhide crackers without liming process has the highest curve which indicates that the cowhide crackers have a hard texture. The lowest curve is owned by the variety of cowhide crackers in the liming process of 93 grams. This indicates that the variety of crackers by soaking in lime as much as 93 grams has a crunchy texture.

This liming process affects the levels of calcium, water, protein, and the swelling of cowhide crackers. In short, soaking the cowhide in a liming solution acts as a hardener and gives a texture to the cowhide crackers. The higher liming concentration resulted in higher levels of calcium, crunchiness, taste, and swelling, while the moisture content and protein content gave lower values on a cracker. Calciumcontaining solutions accelerate the drying rate because calcium-containing solutions can attract water molecules from within the material that they form hydrates and have a harder texture. The more water that comes out of the material, the more pores exist in the network. The more pores that are formed, the looser the structure and the easier it is to break, thus produce higher crispiness. Besides, the higher the liming concentration, the protein removal process runs well, which results in some of the soapy fat into waterinsoluble calcium soap, making it difficult for water to be absorbed into the skin and this increases the swelling power of the cowhide cracker produced. In short, protein affects the volume of enlargement of cowhide crackers. The same as a protein, fat also plays a role in the expansion and crispness of crackers. The fat content in the skin tends to be low, around $0.5-7 \%$. Fat molecules in the skin are bound to protein molecules. During the protein dissolution process, fat molecule dissolves with protein molecules. The high level of fat in cowhide crackers can be caused by the frying process. The frying process causes an increase in food fat content. When the crackers expand, the oil absorbed into the pores along with the evaporation of the water content of the food (Bolade, 2018; Noorakmar, Cheow, Norizzah, Zahid, and Ruzaina, 2012). Apart from affecting hardness and crispness, the liming process also makes food durable and prevents coloration or browning (Hardoko and Utami, 2020).

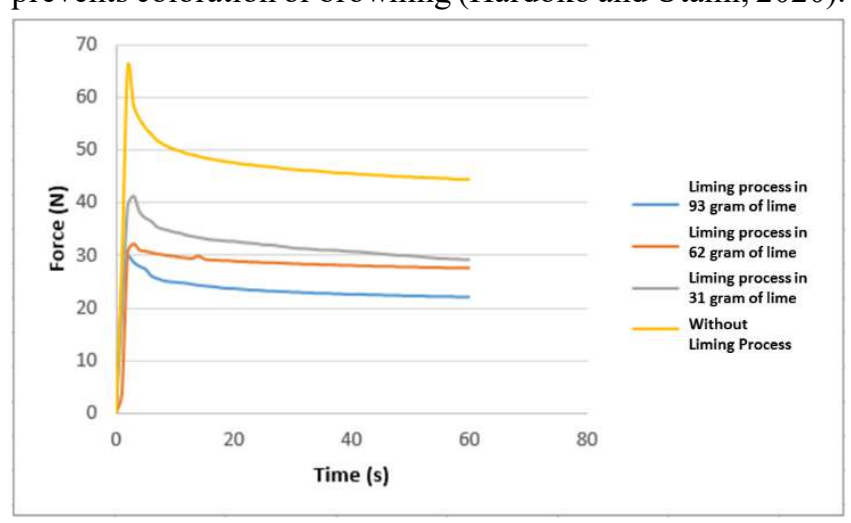

Fig 3. The hardness test of cowhide crackers

Table 1 shows the results of the puncture strength test. In Table 1, cowhide crackers with the liming process in 93 
grams of lime have the highest average. This means that the cracker with this variety has the lowest hardness level compared to other cracker variations. It means the cowhide crackers with 93 grams of lime concentration have a crispy texture. Shore Durometer test shows that the greater the value obtained, the lower the hardness level of crackers. The crackers hardness value indicates the depth of the needle inserted into the cookie. The deeper or greater the hardness value of the crackers, the crispier the cracker.

Table 1. The puncture strength test of cowhide crackers

\begin{tabular}{|c|c|c|c|c|}
\hline No & $\begin{array}{c}\text { Without } \\
\text { Liming } \\
\text { Process }\end{array}$ & $\begin{array}{c}\text { Liming } \\
\text { process in } \\
\text { 31 grams } \\
\text { of lime }\end{array}$ & $\begin{array}{c}\text { Liming } \\
\text { process in } \\
\text { 62 grams } \\
\text { of lime }\end{array}$ & $\begin{array}{c}\text { Liming } \\
\text { process in } \\
\mathbf{9 3} \text { grams } \\
\text { of lime }\end{array}$ \\
\hline 1 & 64 & 65 & 57 & 74 \\
\hline 2 & 66 & 62 & 43 & 69 \\
\hline 3 & 64 & 60 & 45 & 76 \\
\hline 4 & 66 & 68 & 55 & 77 \\
\hline 5 & 68 & 66 & 46 & 78 \\
\hline 6 & 69 & 67 & 55 & 77 \\
\hline Average & $\mathbf{6 6 . 1 6 6 6 7}$ & $\mathbf{6 4 . 6 6 6 6 7}$ & $\mathbf{5 0 . 1 6 6 6 7}$ & $\mathbf{7 5 . 1 6 6 6 7}$ \\
\hline
\end{tabular}

Biodegradation test is also carried out on cowhide crackers to find out how easily the material could be degraded. Table 2 shows the weight loss of each variety of cowhide crackers. Based on Table 2, it can be seen that on the fourth day of testing, all variations of cowhide crackers have reached $>80 \%$ weight loss. When viewed from the liming variation, the crackers without lime are more easily degraded because at each testing period they often get the highest percentage of weight loss among other liming variations. On the other hand, the variety of cowhide crackers with a variation of 93 grams of lime has the lowest weight loss percentage. This happens because of the influence of lime application on the process of soaking the cowhide.

Table 2. Biodegradation test for cowhide crackers

\begin{tabular}{|c|c|c|c|c|c|c|c|}
\hline \multicolumn{7}{|c|}{ Weight Loss (\%) } \\
\hline $\begin{array}{c}\text { Contraction } \\
\text { of Liming }\end{array}$ & D-1 & D-2 & D-4 & D-6 & D-8 & D-10 & $\begin{array}{c}\text { D- } \\
\mathbf{1 4}\end{array}$ \\
\hline $\begin{array}{c}\text { Without } \\
\text { Liming }\end{array}$ & 11 & 76 & 98 & 78 & 15 & 98 & 98 \\
\hline $\begin{array}{c}\text { 31 grams of } \\
\text { lime }\end{array}$ & 11 & 88 & 98 & 25 & 27 & 58 & 98 \\
\hline $\begin{array}{c}\text { 62 grams of } \\
\text { lime }\end{array}$ & 9 & 31 & 98 & 97 & 58 & 98 & 98 \\
\hline $\begin{array}{c}\text { 93 grams of } \\
\text { lime }\end{array}$ & 10 & 30 & 84 & 33 & 92 & 76 & 83 \\
\hline
\end{tabular}

\subsection{Student Demographics}

Table 3 shows the basic scores of students in science subjects (Mathematics, Chemistry, Physics, and Biology). The basic value of students' science is needed to determine the readiness of students in learning science. Based on Table 3 , the average science score of all subjects is greater than 83 , which means that students have good knowledge and skills in science.

Table 3. Students average scores based on students' school report

\begin{tabular}{|l|l|l|}
\hline \multicolumn{1}{|c|}{ No } & \multicolumn{1}{|c|}{ Subject } & Average score \\
\hline 1. & Mathematics & 83.89 \\
\hline 2. & Chemistry & 82.78 \\
\hline 3. & Physic & 81.67 \\
\hline 4. & Biology & 84.44 \\
\hline
\end{tabular}

\subsection{Learning Outcomes Analysis}

Figure 4 shows the pretest and posttest scores of each student. From Figure 4, it can be seen that after treatment in the form of teaching science through experimental demonstration methods the level of student comprehension of the material increased. This can be seen from the posttest scores obtained by students that are better than the pretest scores. However, $16 \%$ of the students do not show progress as envision due to limited interfacial interaction between teacher-student and student-student. Therefore, further study on teaching and learning about food chemical and mechanical composition to students should be conducted to improve students' knowledge and understanding of food chemical composition. Also, limitation in this study should be noted as this study conducted during COVID-19 pandemic outbreak resulting online or distant learning (Adnan and Anwar, 2020; Suryaman, Cahyono, Mmuliansyah, Bustani, Suryani, Fahlevi, and Munthe, 2020).

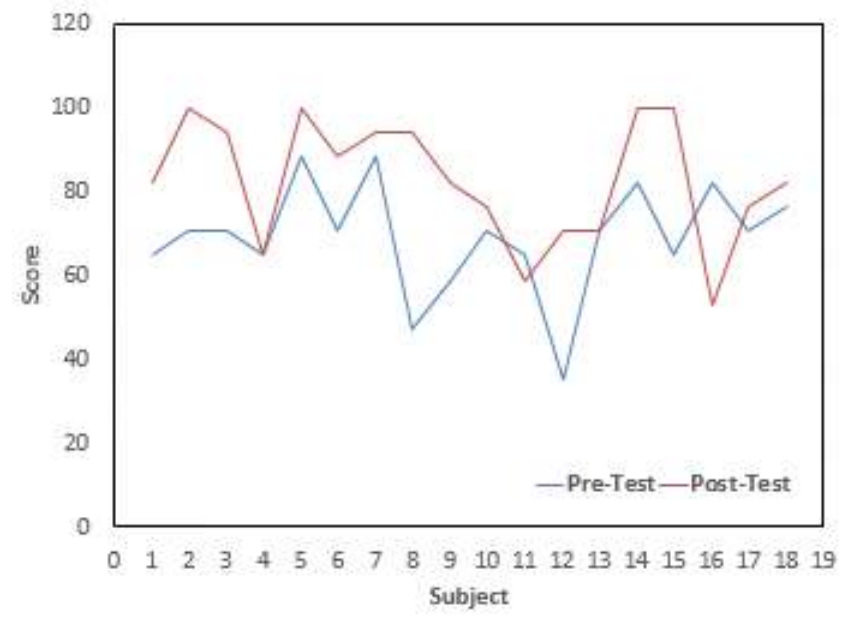

Fig 4. Pre-test and posttest score each student

Based on Figure 4, learning outcomes with experimental demonstration methods show an increase and decrease in student learning outcomes. However, the students' average score increases on their posttest after being presented with 
the experimental demonstration video. To support the results in Figure 4, a Paired t-Test analysis is also performed. Table 4 shows the results of the Paired t-Test. Based on the Paired t-Test test table (see Table 4), the experimental demonstration method shows a significant effect $(\rho<0.005)$ on student learning outcomes with t count as in Table 4.

Table 4. Paired t-Test of pre-test and post-test

\begin{tabular}{|c|c|c|c|c|}
\hline Variable & $\mathbf{n}$ & t-score & Sig. & $\begin{array}{c}\text { Level of } \\
\text { Significant }\end{array}$ \\
\hline $\begin{array}{c}\text { Pretest and } \\
\text { Posttest }\end{array}$ & 18 & 3,267 & 0,000 & 0,05 \\
\hline
\end{tabular}

In this study, the provision of the pretest, presentation of instructional videos, and provision of posttest can be used as the indicator of student learning progress. The provision of pre-test and post-test is useful as a correlation between what is or has been learned and what will be studied so students can easily understand learning materials (Risdianto, Dinissjah, and Nirwana, 2020; Sotáková, Ganajoa, and Babincakova, 2020). Giving students a pretest and posttest brings students to the stage of cognitive growth in interpreting the learning material appropriately during the learning process (Hayati, Bintari, and Sukaesih, 2018). With the introduction of the pretest, students must first plan the material so the process of assimilating the material that has been learned with the material that has just been taught will enhance student progress. Meanwhile, providing a posttest allows students review or draw conclusions of the lessons they have participated and to help what students have absorbed will stay longer in the student memory (Sakuraya, Shimazu, Imamura, Namba, and Kawakami, 2016). Video presentation during the learning process clarifies the presentation of messages and information that it can accelerate and improve the process and student learning outcomes (Warju, Ariyanto, Soeryanto, Hidayatullah, and Nurtanto, 2020). Presentation of learning media through video will increase and focus students' attention so it can contribute to motivational learning.

This is following the study of Nadeak and Naibaho (2020) which states that learning media using video-based learning increases student motivation. Besides, it encourages students to remember what they have learned and encourages students to do continuous improvement, since short videos can provide more flexibility for teachers and can prompt learning directly to students' needs. If the content provided in the learning video is ambiguous, students may re-watch, re-learn, pause, rewind and replay the video to meet student learning needs, thus, motivating students to learn. (Daniela, Kalnina, and Strods, 2017). Sablić, Mirosavljević, and Škugor (2004) also state that video views make students' attention is focused on the lesson.

Besides increasing learning motivation, learning setback can be overcome using video as a learning media. Teachers may use videos to provide teaching material to make it more memorable and simpler, according to the student's characteristics. Through instructional videos, students are expected to get the same and correct perceptions and understanding. Also, learning media can foster students' positive attitudes towards the subject matter, thus, students' diverse interpretations can be avoided. Students who see or hear a description of a subject matter through the same media can receive the exact information that other students receive. Thus, the learning media can reduce the gap in the information received by students (Vijyeta Bhasin, Deaver, and Sarin, 2020). Also, this learning technique encourages the enhancement of student learning and achievement, enhances enthusiasm for learning and affects the positive attitudes of students.

To support the achievement of using instructional videos, several studies show the accomplishment of using instructional video media on student learning outcomes. Fayaz, Mazahery, Hosseinzadeh, Yazdanpanah (2015) conducted research that aimed to determine the effect of a new educational modality by using videotapes on the performance of dental students. It shows that learning with multimedia instruction increases the gain of student learning outcomes than learning using traditional instructions.

Besides, Nadelson, Scaggs, Sheffield, and McDougal (2015) research which aimed to analyze learning process through developing and applying instructional videos show a significant $\mathrm{t}$-test value $(\mathrm{t}=2.26, \mathrm{p}<0.02)$ where the students treated without instructional learning videos only increased the quiz score by $4 \%$, while the students treated with instructional videos increased the quiz score by $10 \%$.

Based on research conducted by Fayaz, Mazahery, Hosseinzadeh, Yazdanpanah (2015) and Nadelson, Scaggs, Sheffield, and McDougal (2015), it shows that the use of learning media in the learning process is more effective because it can generate motivation and increase student learning outcomes. Also, this study shows that the learning process using instructional video is effective as indicated by an increase in the post-test and t-test scores that are significant $(\mathrm{t}=3.267, \mathrm{p}<0.05)$.

\section{Conclusion}

The results of the mechanical characteristics test of cowhide crackers using the hardness test and puncture strength test methods showed that the cowhide crackers with a variation of the concentration of 93 grams of lime has the best level of crispiness. It is a variation that consumers like. The cowhide cracker with the lime-free variety has the highest degradation and the cowhide cracker with a variation of 93 grams of lime has the lowest degradation which means the cracker is more durable than other variations. The learning method through experimental demonstrations with pretest, video presentation, and posttest giving a positive influence on student achievement. The presence of video presentations in science subjects makes teaching materials informative and easier for students to understand.

\section{Acknowledgements}

This study acknowledged RISTEK BRIN for Grant-in-aid Penelitian Terapan Unggulan Perguruan Tinggi (PTUPT) and Bangdos Universitas Pendidikan Indonesia

\section{References}

Adnan, M. and Anwar, K. (2020). Online Learning amid the COVID-19 Pandemic: Students' Perspectives. Online Submission, 2(1), 45-51. 
Ahmed, H., Satheesh, N. and Dibaba, K. (2018). Functional, physical and sensory properties of cookies prepared from okara, red teff and wheat flours. Croatian journal of food science and technology, 10(1), 23-32.

Bolade, M. K. (2018). Physical and organoleptic characteristics of non-sour 'kokoro'(a Nigerian maize-based snack) as influenced by flour particle size differential. LWT, 87, 287-292.

Daluba, N. E. (2013). Effect of Demonstration Method of Teaching on Students' Achievement in Agricultural Science. World Journal of Education, 3(6), 1-7.

Daniela, L., Kalniņa, D., \& Strods, R. (2017). An overview on effectiveness of technology enhanced learning (TEL). International Journal of Knowledge Society Research (IJKSR), 8(1), 79-91

Fayaz, A., Mazahery, A., Hosseinzadeh, M. and Yazdanpanah, S. (2015). Video-based learning versus traditional method for preclinical course of complete denture fabrication. Journal of Dentistry, 16(1), 21.

Handayani, D., Hufad, A., Tukimin, S., Rochyadi, E. and Nandiyanto, A. B. D. (2020). Teaching Ph of Suspension Containing Colloidal Particles Suspension to Students with Deaf and Hard Hearing. Journal of Engineering Science and Technologi, 15, 48-57.

Hardoko, H. and Utami, S. (2020). Chemical-Physical Properties Characterization of White Snapper Fish Skin Rambak Crackers Based on Boiling and Drying Duration. Jurnal Ilmiah Perikanan dan Kelautan, 12(1), 122-130.

Hayati, D. P., Bintari, S. H. and Sukaesih, S. (2018). Implementation of the practicum methods with guideddiscovery model to the student skill of science process. Journal of Biology Education, 7(1), 118-126.

Hidayat, D. S., Rahmat, C., Fattah, N., Rochyadi, E., Nandiyanto, A. and Maryanti, R. (2020). Understanding Archimedes Law: What the Best Teaching Strategies for Vocational High School Students with Hearing Impairment. Journal of Technical Education and Training, 12(1).

Husni, H. (2020). The Effect of Inquiry-based Learning on Religious Subjects Learning Activities: An Experimental Study in High Schools. Jurnal Penelitian Pendidikan Islam, 8(1), 43-54.

Lucky, A., Hosen, A., Toma, M. and Mazumder, M. (2020). Nutritional and sensory quality assessment of plain cake enriched with beetroot powder. Food Research, 4(6): 20492053.

Nadeak, B. and Naibaho, L. (2020). Video-Based Learning on Improving Students' Learning Output. PalArch's Journal of Archaeology of Egypt/Egyptology, 17(2), 44-54.

Nadelson, L. S., Scaggs, J., Sheffield, C. and McDougal, O. M. (2015). Integration of video-based demonstrations to prepare students for the organic chemistry laboratory. Journal of Science Education and Technology, 24(4), 476483.
Nakov, G. and Ivanova, N. (2020). The effect of different methods for production of crackers on their physical and sensory characteristics. Technologica Acta: Scientific/professional journal of chemistry and technology, 13(1), 41-45.

Nandiyanto, A. B. D., Raziqi, G. Y., Dallyono, R. and Sumardi, K. (2020). Experimental Demonstration for Enhancing Vocational Students' Comprehension on Heat Transfer through Conduction and Radiation of Light Bulb. Journal of Technical Education and Training, 12(3), 189195.

Nandiyanto, A. B. D., Fiandini, M., Ragadhita, R., Sukmafitri, A., Salam, H., and Triawan, F. (2020). Mechanical and biodegradation properties of cornstarchbased bioplastic material. Materials Physics and Mechanics, 44, 380-391.

Nishio, Z., Ito, M., Takata, K., Goshima, D., Matsushita, K., Nakamura, T. and Yamauchi, H. (2020). Analysis of the relationship between various soft wheat flour characteristics and cookie quality. Food Science and Technology Research, 26(2): 215-222.

Noorakmar, A. W., Cheow, C. S., Norizzah, A. R., Zahid, A. M., \& Ruzaina, I. (2012). Effect of orange sweet potato (Ipomoea batatas) flour on the physical properties of fried extruded fish crackers. International Food Research Journal, 19(2), 657.

Purba, F., Suparno, O. and Suryani, A. (2020). Green productivity in the indonesian leather-tanning industry. Revista de Pielarie Incaltaminte, 20(3), 245.

Puspitarini, Y. D. and Hanif, M. (2019). Using Learning Media to Increase Learning Motivation in Elementary School. Anatolian Journal of Education, 4(2), 53-60.

Risdianto, E., Dinissjah, M. J. and Nirwana, M. K. (2020). The Effect of Ethno Science-Based Direct Instruction Learning Model in Physics Learning on Students' Critical Thinking Skill. Universal Journal of Educational Research, 8(2), 611-615.

Sablić, M., Mirosavljević, A. and Škugor, A. (2020). Videobased learning (VBL)-past, present and future: An overview of the research published from 2008 to 2019. Technology, Knowledge and Learning, 1-17.

Sakuraya, A., Shimazu, A., Imamura, K., Namba, K. and Kawakami, N. (2016). Effects of a job crafting intervention program on work engagement among Japanese employees: a pretest-posttest study. BMC psychology, 4(1), 49.

Sotáková, I., Ganajová, M. and Babincáková, M. (2020). Inquiry-Based Science Education as a Revision Strategy. Journal of Baltic Science Education, 19(3), 499-513.

Starowicz, M. and Zieliński, H. (2019). How Maillard reaction influences sensorial properties (color, flavor and texture) of food products?. Food Reviews International, 35(8), 707-725.

Suryaman, M., Cahyono, Y., Muliansyah, D., Bustani, O., Suryani, P., Fahlevi, M. and Munthe, A. P. (2020). COVID- 
19 pandemic and home online learning system: Does it affect the quality of pharmacy school learning? Systematic Reviews in Pharmacy, 11(8), 524-530.

Tavares, W. P. S., Dong, S., Jin, W., Yang, Y., Han, K., Zha, F. and Zeng, M. (2018). Effect of different cooking conditions on the profiles of Maillard reaction products and nutrient composition of hairtail (Thichiurus lepturus) fillets. Food Research International, 103, 390-397.

Vijyeta Bhasin, S. P., Deaver, U. J. and Sarin, J. (2020). Effect of Video based Teaching on Knowledge and Attitude regarding ADHD of Children among Primary School Teachers. Medico Legal Update, 20(3), 381-388.

Warju, W., Ariyanto, S. R., Soeryanto, S., Hidayatullah, R. S. and Nurtanto, M. (2020). Practical Learning Innovation: Real Condition Video-Based Direct Instruction Model in Vocational Education. Journal of Educational Science and Technology (EST), 6(1), 79-91.

Widodo, A. P. A., Hufad, A., Sunardi. and Nandiyanto, A. B. D. (2020). Collaborative teaching in heat transfer for slow learner students. Journal of Engineering, Science and Technology, 15, 11-21. 